\title{
Editorial
}

It seemed entirely appropriate, on reaching the one hundredth issue of Library and Information Research (and its predecessors), that we should do something special to celebrate. What better way then, than to invite the great and the good of the library and information world to contribute their views on the past, present and future state of research in our profession? Of course, if one targets such a group of luminaries, one must expect two things to happen. First, such folk are always extremely busy - so we are very grateful that they agreed to write for us at all; and second, with such a (deliberately) vague brief, this group of independent thinkers are inevitably going to respond in a variety of different ways. This issue is far from bland and repetitive!

To set the scene, Stephanie Kenna reports on the most significant development in library, archive and information science research (LAIS) for many years - the LAIS research coalition. Kenna describes the development of the coalition from its origin at the 'Looking Back to the Future' workshop held at the British library in 2006 (and fully reported in the first online issue of this journal, volume 31, number 97), through an extensive consultation process, to the handover of responsibility to an Implementation Group tasked with formally establishing the coalition later this year. The level of cooperation and support achieved by the Steering Group from stakeholders is unprecedented. As a new research agenda is defined and promulgated it is clearly an exciting time for LIAS researchers everywhere.

We were searching for viewpoints from different areas of the profession, both geographically and occupationally. Peter Reid rose admirably to the challenge with an interesting discussion of practitioner research in Scotland from the perspective of an educator of future library and information professionals. Reid emphasises the strong links between practice and academe in Scotland and the importance of collaboration between the two communities; his message is clear: we need to move beyond talk to meaningful collaborative action.

David Streatfield is well used to collaboration in his role as "consultancy researcher' or, as he describes it, "the invisible player in the LIS sandpit". In his fascinating paper, Streatfield first describes the recent history of consultancy research then looks ahead to LIS policy and practice in the next ten years and beyond. He notes that whilst some existing themes, such as how people seek and obtain information, will continue to occupy researchers, there will also be interest in new areas, for example how people engage with information in sense-making. Streatfield, more than any other author in this collection, puts his neck on the line in predicting the future of LIS research but, helpfully, he also describes the skills that future researchers will need for this. Current and aspiring researchers take note!

For England and Wales, Javier Stanziola, Head of Research and Evidence at the Museums, Libraries and Archives Council (MLA), takes a systematic view of the social and economic drivers of change in the UK and then proposes several scenarios of how libraries, museums and archives might respond to these changes. Any future research agenda, he argues, must support these scenarios. For 
example, in Stanziola's third scenario "work currently labelled as 'social inclusion', 'outreach' and 'identity-building' by most libraries, museums and archives becomes integrated into their main marketing and public relations functions". Stanziola argues that applying existing methodologies, possibly from other disciplines, may be the most effective way of measuring the outcomes and impact of such changes.

The remaining two papers are very personal accounts of research from the point of view of an academic, Paul Sturges, and a workplace research librarian, Steve Thornton. Some may find Sturges's paper somewhat controversial - he argues for a more straightforward, qualitative approach to research and the importance of "imaginative devising and matching of methods to circumstances in the field". Not for him the number crunching of the major quantitative study - Sturges believes strongly that the "small but interesting topics and tentative, exploratory projects... all respond best to qualitative work". No doubt this will come as something of a relief to those without a quantitative bent! Thornton's offering too, is strongly rooted in the day to day realities of practitioner research. Having started with some observations concerning what one needs to be a workplace researcher, Thornton then offers a 'warts and all' analysis of his experiences in three separate research projects - periodical procurement, measuring library performance and cataloguing workflow. Practitioners will be able to identify with all three of Thornton's projects and will undoubtedly learn from both his process and his outcomes. And if that isn't enough to persuade you, Thornton's writing style is entertaining too.

If the articles in this issue inspire you, infuriate you or otherwise provoke you to comment, do please consider posting a comment to the journal. You will need to register first and navigate to the article of your choice, but then you simply click on 'Add comment' to have your say. To see what others have written, just click 'Cancel' instead of 'Save' on the 'Enter comment' page.

It has been a privilege and pleasure to edit this issue of Library and Information Research, we hope you enjoy it as much as we did.

\section{Miggie Pickton}

Louise Cooke 